\title{
ETIŠKO VADOVAVIMO RAIŠKA ORGANIZACIJOJE
}

\author{
Arnoldas Petrulis ${ }^{1}$, Ligita ŠimanskienĖ², Darius Burgis ${ }^{3}$, Jurgita Paužuoliené ${ }^{4}$
}

Klaipėdos universitetas (Lietuva)

\begin{abstract}
ANOTACIJA
Straipsnyje atskleista etiško vadovavimo svarba organizacijų veikloje. Etiškas vadovavimas - tai asmeniniu, teigiamu pavyzdžiu, remiantis asmeninėmis vertybemis ir visuotinai priimtinomis etikos normomis, formuojama elgsena, kreipianti darbuotojų veiklą, pasitelkus pasitikẻjimą, siekiant sėkmingai ịgyvendinti tikslus: savo, darbuotojų, organizacijos, visuomenès. Sprendžiama mokslinė problema, kaip pasireiškia etiškas vadovavimas organizacijoje, siekiama išsiaiškinti, teiraujantis apie vadovavimo etiškumą, ar vadovo ir jam tiesiogiai pavaldžių darbuotojų požiūris sutampa. Atlikti du kokybiniai tyrimai organizacijoje: interviu su vadovu ir fokus grupės interviu su tiesiogiai vadovui pavaldžiais darbuotojais. Tyrimo rezultatai atskleidžia, kad iš dalies dirbama esant etiškam vadovavimui, vadovas laikosi etikos principų, bet vadovo ir jam tiesiogiai pavaldžiu darbuotojų požiūris į etišką vadovavimą dažnu atveju skiriasi.

PAGRINDINIAI ŽODŽIAI: etiškas vadovavimas, vadovas, fokus grupe, interviu.
\end{abstract}

JEL KLASIFIKACIJA: M12, O15.

DOI:

Ivadas

Etiško vadovavimo svarba apibrežiama, kaip priimtinos darbo aplinkos kūrimas ir tarpininkavimas tarp organizacijos ir asmenų, kurie tarpusavyje susiję, vertinami ir gerbiami (Khodarahmi, Aghahoseini, 2014: 281-282). Etiškas vadovavimas tapo pagrindu siekiant suvokti vadovavimo pasekmes verslo organizacijose (Nyukorong, 2014: 56). Etiško vadovavimo atveju visada pabrezžiamas atliekamo darbo prasmingumas ir galimas poveikis grupės nariams, organizacijai ir net visai visuomenei, kad sekejjai, suvokę užduoties svarbą, stengtųsi kurti naujas idèjas, tai prisidèdami prie organizacinių tikslų igyvendinimo. Etiškam vadovavimui būdingas sąžiningumas, dora, altruizmas, įsipareigojimas organizacijai. Darbuotojams tai teikia psichologinį saugumą, nes žino, kad pateikiant naujas idejas bus laikomasi etikos principų ir tai skatins dalytis savo žiniomis su bendradarbiais. Darbuotojai, jaučiantys, kad vadovai juos gerbia, paiso jų poreikių, vertina talentus ir skatina tobulèti, labiau linkę tobulèti, mokytis, vertinti savo žinias ir gebejjimus diegiant darbe naujoves. Remiantis P. A. Obicci (2015: 3) atliktais tyrimais, etiškai vadovaujant sudaromi lygiaverčiai, bendromis vertybèmis ir sąžiningumu paremti, darbuotojus ir verslą susiejantys santykiai. Kartu etiškas vadovavimas skatina darbuotojų priimtiną elgseną, didžiuotis organizacija ir labiau jai

1 Arnoldas Petrulis - asistentas, doktorantas, Klaipėdos universiteto Socialinių ir humanitarinių mokslų fakulteto Vadybos katedra Moksliniai interesai: etiškas vadovavimas, vadovavimo stiliai

El. paštas: arnoldas.petrulis@gmail.com

2 Ligita Šimanskienè - profesorè, daktarè (socialiniai mokslai), Klaipėdos universiteto Socialinių ir humanitarinių mokslų fakulteto Vadybos katedros vedèja

Moksliniai interesai: etiškas vadovavimas, organizacinės kultūros kūrimas

El. paštas: ligita.simanskiene@gmail.com

3 Darius Burgis - asistentas, Klaipedos universiteto Socialinių ir humanitarinių mokslų fakulteto Vadybos katedra

Moksliniai interesai: krizinių situacijų valdymas, organizacijų valdymas

El. paštas: burgis.darius@gmail.com

4 Jurgita Paužuolienė - lektorè, socialinių mokslų daktarè, Klaipėdos universiteto Socialinių ir humanitarinių mokslų fakulteto Vadybos katedra

Moksliniai interesai: etiškas vadovavimas, organizacinès kultūros kūrimas

El. paštas: j.pauzuoliene@gmail.com 
ịsipareigoti, padeda jiems geriau suvokti veiklos esmę. Etiškas vadovavimas lemia svarbius darbuotojų rezultatus, nes nustatytas teigiamas etiško vadovavimo ir darbuotojų pastangų tarpusavio ryšys. Toks vadovavimas užtikrina psichologinị saugumą, yra susijęs su darbuotojų savo ịtakos organizacijos veiklai suvokimu ir palankiai paveikia daugelio darbuotojų rezultatus (Ciulla, 2004: 304).

Todèl mokslinè ir praktinè problema gali būti formuluojama probleminiais klausimais: ar etiškas vadovavimas būdingas organizacijai, koks vadovo ir jam tiesiogiai pavaldžių darbuotojų požiūris ị etišką vadovavimą?

Tyrimo tikslas - atskleisti etiško vadovavimo organizacijoje raišką.

Tyrimo metodai: siekiant pagrịsti vadovų ir darbuotojų supratimą bei etiško vadovavimo raišką remtasi mokslinès literatūros įžvalgomis, atlikta analizè, sintezè, palyginimas. Atlikti du kokybiniai tyrimai: su darbuotojais - fokus grupès interviu, su vadovais - interviu. Interviu duomenys transkribuoti. Pasitelktas grafinis duomenų vaizdavimas.

\section{Etiško vadovavimo svarba}

Etiškas vadovavimas organizacijoje užtikrina etinį kontekstą (etiško elgesio modelis, politika, santykiai, užduotys), vadovas inicijuoja ir valdo socialinio išmokimo procesus (Stelmokienè, Endriulaitienè, 2013: 115). Tikètina (Zhu, 2008: 65), kad etiško vadovavimo veikiami sekejjai (darbuotojai) galètų peržengti savo ego, savus interesus ir poreikius, nes vadovautųsi nusistatyta moraline tapatybe (Mihelič, Lipičnik, Tekavčič, 2010: 33), atsižvelgdami ị vadovo nesavanaudiškus veiksmus darbuotojų ir organizacijos labui. Būtent (Pandey, Singh, Pathak, 2015: 93) etiškas vadovavimas sulaikydavo asmenis nuo neetiškų sprendimų prièmimo, o etiškai besielgiantys vadovai puoselèdami sąžiningus santykius su sekẻjais (darbuotojais) kuria organizacijai naudingus santykius, taip dèdami tvirtą etiškumo pagrindą. Tyrimo rezultatai atskleidè (Nyukorong, 2014: 57), kad etiškas vadovavimas veikia darbuotojus: teikia emocini pasitenkinimą, pasitenkinimą darbu, skatina ịsipareigoti organizacijai (Yates, 2014: 24), perimama organizacine elgsena. Vadovavimas gali būti svarbus socialinès ịtakos šaltinis (Zhu, 2008: 62).

Pripažịstama (Chin, 2013: 17), kad vadovybès asmeninis elgesys ir taikomi etikos principai atlieka svarbų vaidmenį formuojant ir diegiant organizacijoje etišką elgseną. Geriausias būdas tokią elgseną valdyti (prižiūrèti, kad būtų laikomasi nustatytų normų) - elgsenos derinimas (Treviño, Brown, 2004b: 80), siekiant formalioje (organizacinejje) ir neformalioje (organizacijos) kultūrose elgtis teisingai. Jei vadovas elgiasi moraliai, be to, yra malonus žmogus (Derr, 2012: 67), daugelis darbuotojų stengsis imituoti (kopijuoti) tokią elgseną, kuri prisidès prie organizacijos etiškumo ir bendruomenès pagarbos.

Etiškai vadovaujant svarbu (Aghiorghiesei, Poroch, Perțea 2015: 190): nuosekliai kurti ir skatinti vienas kitam neprieštaraujančius procesus, įžvalgiai juos kreipiant ị ateitị, remti darbuotojų dalyvavimą ir jų gebejjimą mokytis, deleguoti (dalintis) valdžia, skatinti nuomoniu įvairovę, sudarant tinkamas darbo sąlygas, kurti ir tobulinti tarpusavio santykius, puoselèti bendruomeniškumą, prisiimti atsakomybę, nustatyti žmonèms prioritetus etiškumo aspektu, skatinti bendradarbiauti, puoselèti pasitikejjimo kultūrą. Etiškas vadovavimas apima (Bass, Steidlmeier, 1999: 182): 1) moralų vadovavimą; 2) etikos vertybių teisètumo įprasminimą vadovų vizijoje, jų aiškumą (suprantamumą) ir programą, kurią sekèjai (darbuotojai) arba priima, arba atmeta; 3 ) socialinès etikos pasirinkimą ir veiksmus, kai vadovai ir pasekejjai veikia (dirba) kartu ir siekia, kad jų veikla būtų morali. W. G. Rowe ir L. Guerrero (2013: 492) pateikia tokias etiško vadovavimo nuostatas: pagarba, tarnavimas (pagalba) kitiems, teisingumas, sąžiningumas kitų atžvilgiu, bendrystès su kitais puoselèjimas.

Choi So-Yun (2015: 33) teigimu, etiškas vadovavimas leidžia organizacijai užsitikrinti organizacinị teisètumą (išvengti klaidingų sprendimų), stiprinant organizacinị ịvaizdị iš išorès ir vidaus, didinti organizacinị veiksmingumą, skatinant priimtiną nario organizacinę elgseną (pavyzdžiui, organizacinio ịsipareigojimo ir pilietiškumo, pasitenkinimo darbu). Be to, etiškas vadovavimas teigiamai veikia organizacinį veiksmingumą, skatina organizacijos narių sąžiningumą ir atsakomybę. Kvalifikuoti darbuotojai visada siekia patys priimti sprendimus. Jie ypač vertina galimybę priimti darbinius sprendimus nespaudžiami iš išorès, tai gali lemti jų sprendimus ir darbo ịpročius. Organizacija, orientuota ị valdžios pasidalijimą, mažina streso lygị ir vadovų bei darbuotojų tarpusavio konfliktus, dèl to darbuotojų pasitenkinimo lygis kyla. Darbuotojo dalyvavimas leidžia jam geriau suvokti savo vaidmenį ir labiau įsipareigoti dèl darbo našumo. 
Etiško vadovavimo galimybė daryti ịtaką darbuotojų veiklai priklauso nuo: elgsenos motyvacijos, ịkvèpimo ir asmeninio požiūrio (Alshammari, Almutairi, Thuwaini, 2015, p. 112). Akivaizdu, kad kokybiškus santykius lemia pasitikèjimas ir pagarba - svarbiausi sėkmę lemiantys veiksniai. Dèl to etikos normomis besivadovaujantys vadovai atlieka pagrindinị vaidmenị, siekdami, kad santykiai peraugtụ ị etišką, bet natūralią organizacijos gyvavimo būseną, kai vadovaujamasi etikos principais (sąžiningumas, pagarba, teisingumas), kuriama patikima ir nešališka aplinka. Taigi esant etiškam vadovavimui, dèmesị reikètų sutelkti ties moralinėmis vertybėmis ir taip daryti poveikị darbuotojams bei kurti teigiamą organizacijos įvaizdị.

Organizacijoms etiškas vadovavimas yra naudingas (Derr, 2012: 68), kadangi gerina reputaciją ir kelia darbuotojų moralès lygị. Etiškumas gali būti išreikštas per organizacijų socialinę atsakomybę, organizuojant socialinę veiklą, skatinant pilietiškumą, kritiškai vertinant ir sąmoningai priimant sprendimus. Gebèjimas priimti kritiką, atvirai reikšti nuomonę, tolerancija kitam asmeniui, socialinis pasitikejjimas, solidarumo su bendradarbiais svarbos pripažinimas, aktyvus dalyvavimas organizacijos bendruomenès gyvenime - tai veiksniai, galintys lemti organizacijos patrauklumą. Laikantis etiško vadovavimo principų (Zhu, 2008: 64-65), taikomi vidiniai etiško elgesio normų modeliai ir moraliniai pavyzdžiai, darbuotojai skatinami nusistatyti savo vidinius moralinius principus ir idealus, kurie taptų etiškos tapatybès pagrindu ir taptų etiškais poelgiais. Pasitelkus etiško vadovavimo pavyzdžius darbuotojai mokomi suvokti etines problemas ir pasiruošti jas spręsti (Mayer, Kuenzi, Greenbaum, 2010: 8), taikant aukštus etinius standartus, kad būtų igyvendinti verslo tikslai, net esant dviprasmiškoms situacijoms (Mihelič, Lipičnik, Tekavčič, 2010: 32), kai, esant kelioms suinteresuotosioms šalims, susiduria skirtingi interesai, vertybès, įsitikinimai. Tikètina (Treviño, Brown, 2004a: 72), kad darbuotojams svarbu matyti ir suvokti etišką vadovavimą, kad jie būtų patenkinti vadovavimo veiksmingumu, taip didètų pasirengimas labiau atsiduoti darbui, noras pranešti apie kylančias problemas ir pasiūlyti, kaip jas spręsti. Laikantis etiško vadovavimo nuostatų (principų) kuriami tarpasmeniniai santykiai su darbuotojais, o pasitelkus organizacinius gebejjimus siekiama patenkinti žmonių poreikius, numatant iggyvendinti užsibrèžtus tikslus, kurie neatsiejami nuo asmeninio ir kolektyvinio augimo, meistriškumo (Khodarahmi, Aghahoseini, 2014: 282). Toks požiūris kuria gerovès ir saugumo atmosferą.

Apibendrinant galima teigti, kad etiškas vadovavimas - tai asmeniniu teigiamu pavyzdžiu, remiantis asmeninėmis vertybėmis ir visuotinai priimtinomis etikos normomis formuojama elgsena, kreipianti darbuotojų veiklą, pasitelkus pasitikèjimą, sėkmingai įgyvendinti tikslus: savo, darbuotojų, organizacijos, visuomenès.

\section{Etiško vadovavimo raiškos tyrimo eiga ir rezultatai}

Etiškam vadovavimui tirti pasirinktas kokybinis tyrimas: interviu ir fokus grupès (Kardelis, 1997: 7475; Tidikis, 2003: 355-356). Tyrimas atliktas asmeninio pokalbio (bendravimo) būdu (Kothari, 2004: 17), siekiant gauti atsakymus ị iš anksto parengtus klausimus interviu. Tyrimo metu apklaustas pasirinktos organizacijos padalinio vadovas, kuris asmeniškai sutiko būti apklausiamas, ir tiesiogiai jam pavaldi pavaldinių grupè. Atskirai atliktas interviu su vadovu ir atskirai - su pavaldiniais (fokus grupe). Siekta sužinoti nuomones tirtu klausimu. Remtasi respondentų vartojamais terminais, neprimetant savo išankstinių schemų (Rupšienè, 2007: 63). Diskusijų grupè (fokus grupè) sudaryta iš 6 asmenų (iš vieno organizacijos padalinio, turinčio bendrą tiesioginị vadovą, kuris apklaustas interviu metodu). Diskusijų grupès metodas (fokus grupè) taikomas, kai interviu atliekamas mažoje grupeleje žmonių, kuriems būdingos tos pačios charakteristikos (Rupšienė, 2007: 87). Tyrimas atliktas Klaipėdos miesto organizacijoje 2019 metų birželio mènesị.

Demografinès tiriamųjų charakteristikos. Tiriamos organizacijos padalinio vadové - moteris, turinti trejų metų vadovavimo šiai organizacijai stažą (interviu truko 45 minutes), fokus grupès šeši tiesiogiai pavaldūs darbuotojai - moterys, kurių darbo stažas šioje organizacijoje sudaro nuo 4 iki 6 metų (interviu truko 41 minutę).

Toliau tekste bus vartojami šie trumpiniai: V1 - vadovo žodžiai; FG1 - fokus grupès pateikti atsakymai i t klausimus. Skliausteliuose nurodoma pateikto teiginio transkribavimo eilutè.

Pirmas klausimas pateiktas tiek vadovui, tiek fokus grupès dalyviams, kaip jie supranta, kas yra etiškas vadovavimas. Organizacijos vadovas, nors ir teigè, „nu man sunku pasakyti“(V1, 11), atsakydamas ị įžanginị klausimą, sakè manąs, kad etiškas vadovavimas, ,kada viskas sustyguota, taip, kad nereiktų eiti baksnoti, badyti, rèkti ir tvar- 
kytis. Kai vadovas vadovaujasi įmonės organizacijos vertybėmis, kurios atitinka jo vertybes ir jas sugeba perleisti jo pavaldiniams ir kolegoms“"(V1, 10-13). Darbuotojai atsakydami ị ši klausimą teigè, kad etiškas vadovavimas, kai „laikomasi visų etikos moralès normų. Nèra, nežinau, va, diskriminacijos kažkokios, pažeminimų“ (FG1, 4-5).

Paklausus, kaip vertinami darbuotojai, ar vertinant atsižvelgiama ị etikos nuostatas, vadovas teigia, kad darbuotojai pagal organizacijos taisykles ir nuostatas vertinami nevienodai. „Tikrai ne. Būna visko, būna ir išlygų, ir atitinkamai pagal situacijas. Iš tikrujų stengiuosi žiūreti pagal asmenybę, stengiuosi kiekvieną kartą individualiai pasižiūrèti“ (V1, 20-22), „vis tiek vadovaujuosi organizacijos taisyklèmis, vertybėmis“ (V1, 22-23). Darbuotojai, atsakydami ị klausimą dèl vadovo darbuotojų vertinimo, remiantis organizacijos taisyklemis ir priimtomis nuostatomis, pateikè atsakymą: „Taip, bet...“ (FG1, 13), leisdami suprasti, kad vadovo vertinimas jų nelabai tenkina. „Kai matau, kad reikia perskirstyti krūvius, taip ir padarau. Aš esu linkusi ieškoti geriausių variantų darbuotojams“ (V1, 26-27). Darbuotojai ị tą patį klausimą, ar vadovas turètų vienodai paskirstyti užduotis, atsižvelgdamas ị darbo krūvius, pateikè atsakymą: „taip, turètų“(FG1, 26). Pateikus patikslinamajji klausimą, ar taip daro, vieni darbuotojai buvo linkę tam pritarti (,aš taip galvoju“, FG1, 26), kiti - „nu nelabai“ (FG1, 26); „,manau taip, ne visada, bet taip“ (V1, 30). Paprašius vadovo patikslinti, kada darbuotojus vertina vienodai ir kaip pasirenka, kuriam skirti užduotis, jis pateikè atsakymą: „Jeigu tai ịkrenta darbas, kurio niekada neturèjo žmogus, tai reiškiasi aš nesugebu arba neįvertinau pati to žmogaus galimybių. Jei tai nusistovejęs darbas, kuriame niekada nebuvo iš to žmogaus signalo, kad nesugeba, ir visada vyko rutiniškai, tai manau, kad ne" (V1, 30-33). Iš vadovo atsakymų galima daryti išvadą, kad jis stengiasi nuolat stebèti, kaip dirba jam pavaldūs darbuotojai, viena dalimi jis labiau pasitiki, kitais - šiek tiek mažiau.

Teirautasi, ar bendruomeniškumo skatinimas ir patyčių prevencija yra tiesioginė vadovo funkcija? „Jei tai būtų mokykla, sakyčiau, taip, vienareikšmiškai, nes tai yra besiformuojantys asmenys. Ar darbovietēje yra patyčių? [Tyrẻjui linktelèjus] Rimtai? Tai aš tada labai laiminga, gimusi po laiminga žvaigžde. Nes niekada nepatyriau tokių dalykų. Ir neleidau sau ir niekada nepagalvojau dèl tokių dalykų“(V1, 58-61). ,Žinokite, aš tada galiu pasakyti nuoširdžiai - aš su tokiais dalykais darbe nesu susidūrusi nei karto“ (V1, 64-65). ,Šitoj vietoj tikrai neturiu, nei nuomonès, nei patirties. Ir aš tikrai galvojau, kad tokie dalykai neegzistuoja“ (V1, 68-69). Darbuotojai taip atsakè ị šį klausimą: „Šiaip patyčių klausimas, nežinau, man atrodo šiek tiek egzistuoja ịmonèj“ (FG1, 44). „Tarkim, tai pirmiausia turi ateiti iš vadovo, jeigu jisai leidžia tokị elgesị, tai pavaldiniai kartais netgi nesąmoningai perima tą modelį. Ir nori nesąmoningai įsiteikti vadovui. Ir jeigu jis neužkerta kelio, tai taip ir yra“ (FG1, 62-65). Teirautasi, ar jūsų padalinyje tai pasitaiko, atsakyta: „Būna kartais“ (FG1, 65). Užduotas tikslinamasis klausimas, ar vadovas pats taip elgiasi, darbuotojai patikino, kad taip: „Vadové? Taip“ (FG1, 65). Taigi bendruomeniškumo ir patyčių klausimu vadovo ir pavaldinių nuomonés nesutapo: nors vadovas kategoriškai teigè, kad nei pats leidžiasi žeminamas, nei taip elgiasi su darbuotojais, darbuotojų teigimu, darbovietėje tokių atvejų pasitaiko norint ịtikti vadovui. Tai aiškus signalas, kad darbuotojai nori / stengiasi ịtikti vadovui tam tikrais klausimais ar kitų darbuotojų atžvilgiu elgdamiesi neetiškai. Galimos kelios tokio elgesio priežastys: arba vadovas elgiasi labai autokratiškai ir darbuotojai bijo, arba darbuotojai nepalankiai nusiteikę naujo vadovo atžvilgiu ir visus pokyčius darbe, darbo kokybės reikalavimus vertina kaip priekabiavimą ar patyčias.

Kitas klausimas - o jums, pavyzdžiui, kaip vadovui privalu paaiškinti, kas teisinga ir kas neteisinga, atsižvelgiant ị etines normas? „Ir aš labai dažnai tą darau, ne tiek aiškinti, bet iš tikrujų mes kartais padiskutuojame“ (V1, 72). „Aš inicijuoju pati, labai dažnai, ateikite kavos“ (V1,75). „Nu gi nesi aklas. Matai ir stebi. Tai nežinau, gal ką nors ir pražiūriu. Ir pati, nu, esu tas artimas vadovas“(V1, 77-78). Darbuotojams užduotas tikslinamasis klausimas: jeigu jums nepaaiškina organizacijos etikos normų, ar jūs elgiatės etiškai? Darbuotojai atsakè: „Nu, kad tikriausiai patys. Kažkaip.“ (FG1, 69). Tyrèjas: „Tvarkoj, o yra buvę taip, kad aiškintų?““ „Aš neprisimenu. Aš irgi. Nu, aš tai [purto galvą]" (FG1, 71-72). Panašu, kad etikos klausimais šioje organizacijoje nepakankamai diskutuojama, nors vadovas teigia, kad etinius klausimus kelia ir skatina diskutuoti, bet darbuotojams to nepakanka. Jie turbūt labiau remiasi bendražmogiškomis vertybėmis ir bendromis etikos normomis. Pastebėta, kad darbuotojai atsargiai renka žodžius ị pateiktus klausimus, vis susižvalgo prieš atsakydami, yra gana baugštūs.

Pasiteiravus, ar turètumète darbuotojus supažindinti su savo asmeninėmis vertybėmis, gauti tokie atsakymai: „Aš labai atsakingai žiūriu ị vertybes“ (V1, 93-94). Vadovo teigimu, jo vertybès tvirtos: „Turbūt ịeina ị penketuką“ (V1, 95); „Tai, kaip gali vadovas nedeklaruoti vertybių? Jos turi būti ir deklaruojamos, ir ne tik deklaruojamos, bet 
dar ir veikti pagal jas ir rodyti pavyzdị. Nes tu negali kalbèti darbuotojams apie skaidrumą, kai pats imi kyšius“(V1, 95-97). Paklausus darbuotojų, ar vadovas turètų sąžiningai išsakyti, kokios yra jo asmeninès vertybès, pateikti atsakymai: „Jo asmeninès?“(FG1, 75); „Gal. Jeigu susiję su darbu, tai gal ir turètų pasakyti“ (FG1, 75-76). Papildomai pasiteiravus, ar organizacijoje suformuotos organizacinès vertybės, darbuotojai atsaké, kad neturi: „Nu, kad nėra“ (FG1, 87). Tyrimu nustatyta, kad vadovas, bent jau žodžiu, labai nori, kad organizacijoje būtų aiškios, darbuotojams suprantamos vertybès, kuriomis organizacija ir vadovautussi. Bet akivaizdu, kad darbuotojams tai nežinoma, jie apskritai apie tai nesusimąsto, neturi nuomonès tuo klausimu.

Vadovo pasiteiravus, kaip organizacijoje formuluojami tikslai, kuriama misija ar vizija, atsakymas šiek tiek nustebino, nes tyrimui pasirinkta organizacija yra labai pelninga, tad tikètasi, kad tikslai tiksliai suformuluoti. „Šita organizacija pirma, kai apie organizacijos tikslus, siekius nèra kalbama. Ir man tai labai keista“(V1, 104-105). „Nei kažkokių tikslų, nei metinių vertinimo pokalbių“(V1, 105-106). Vadovas tikisi, kad tai bus sutvarkyta. „Čia yra sovietinè kultūra, kur tas pats autoritarinis režimas yra labai gajus, tačiau mano skyriuje to nèra. Ir labai daug kas stebisi“ (V1, 110-111). Darbuotojų teigimu, „nuolat kalbama, perrašinejja misijas, visokias užduotis pastoviai“ (FG1, 86). Pasiteiravus apie organizacijos tikslą, misiją, gautas toks, švelniai tariant, abstraktus atsakymas: „Mūsų tikslas - didinti, gerinti, tobulinti ir [šypsniai] taip toliau“ (FG1, 96-97). Ir vèl vadovo ir darbuotojų nuomonès nesutapo. Nors šiuo atveju darbuotojai teigè, kad tikslai peržiūrimi, misijos formuluotės tikslinamos, konkrečiai kažką įvardyti nesugebėjo. Vadovo nuomone, tikslai ir misija net neformuluojami. Vadovo teigimu, „kai aš atėjau dirbti, vienas iš pirmujų mano klausimų buvo, kai aš susipažinau, tet a tet, individualūs pokalbiai, kaip ir kas, ir kur. Aš jų paklausiau, ar žinote savo organizacijos misiją, viziją ir vertybes. Nei vienas nežinojo“(V1, 213-215). Pauzè. „Tai...“ Iš vadovo veido išraiškos galima teigti, kad šiai organizacijai tai nesvarbu. Darbuotojas atsakė: „Nu, čia aš nežinau“ (FG1, 134). Kiti palinksėjo galvomis. Taigi dar kartą patvirtinama, kad aukštesnio lygmens vadovai tam neskyrė dèmesio, o darbuotojai ị tokius klausimus net nesigilina, nes tik vykdo tiesiogiai nurodytas užduotis.

1 lentele. Etiškumo raiška vertybių organizacijoje aspektu

\begin{tabular}{|l|l|l|l|}
\hline Kategorija & Subkategorija & \multicolumn{2}{l|}{$\begin{array}{l}\text { Etiškumo dažnis pasi- } \\
\text { sakymuose }\end{array}$} \\
\cline { 3 - 4 } & & V1 & FG1 \\
\hline \multirow{4}{*}{ Vertybės } & Sprendimų prièmimas & 2 & 0 \\
\cline { 2 - 4 } & Užduočių pateikimas & 2 & 4 \\
\cline { 2 - 4 } & Atsakomybės pasidalijimas & 3 & 0 \\
\cline { 2 - 4 } & Požiūris ị iniciatyvą & 1 & 2 \\
\cline { 2 - 4 } & Požiūris ị darbuotojus & 10 & 1 \\
\cline { 2 - 4 } & Požiūris ị savo žinias & 4 & 0 \\
\cline { 2 - 4 } & Bendravimas su darbuotojais & 9 & 4 \\
\cline { 2 - 4 } & Santykių su darbuotojais pobūdis (ugdymas) & 12 & 4 \\
\cline { 2 - 4 } & Požiūris ị drausmę & 5 & 2 \\
\cline { 2 - 4 } & Požiūris ị vertybes & 2 & 0 \\
\cline { 2 - 4 } & Vizijos pateikimas & 5 & 0 \\
\hline
\end{tabular}

Šaltinis: sudaryta darbo autorių, remiantis vadovo (V1) ir fokus grupès (FG1) atsakymais

Iš 1 lentelèje pateiktų duomenų matomi pagal etiško vadovavimo kriterijus išrinkti pasikartojantys etiškumo dažniai vertybių aspektu. Matome, kad vadovas kur kas dažniau remiasi tam tikrais kriterijais nei darbuotojai. Darbuotojai daugiau paminėjo tik užduočių teikimo kategorijoje. Taigi galima teigti, kad darbuotojai susitelkę ties užduotimi, santykiais su bendradarbiais, kiti aspektai juos kur kas mažiau domina ar visai jų kalboje neišryškėja. Lentelè iliustruoja, kad šios organizacijos konkretaus padalinio vadovas kur kas geriau suvokia, kaip svarbu organizacijoje kurti etišką aplinką, puoselèti vyraujančias vertybes, bet darbuotojams tai nerūpi, jie apie tai nesusimąsto. 
I klausimą, kaip formuluojamos užduotys, vadovas atsakè: „Užduotys kaip pateikiamos? Dažniausiai sèdame visi ir kalbamès. Ir tokiu būdu“ $(\mathrm{V} 1,131)$. Darbuotoju teigimu, ,yra duodama užduotis ir viskas, ir tu turi ịvykdyti, ir viskas“ (FG1, 109). Pasiteiravus, ar paaiškinamas užduočių paskirstymas, paaiškejjo, kad vyksta susirinkimai, kur kalbama apie užduočių atlikimą ir paskirstymą: „Ne, nu, ir parašo, ir pasako per posèdžius, kad ten reikia tą, tą, tą padaryti“ (FG1, 110). Dar pasitikslinus, kaip vis tik užduotys skirstomos, pagal atsakomybę ar asmenines savybes, atsakyta: „Paskirsto. Paskirsto, kiekvienam pagal pareigybę, atsakomybę. Neduodama ten, nemanau, kaip pasakyti, nemanau, tų darbų, kaip sako, čia ne mano darbas, vis tiek pagal atsakomybę“ (FG1, 112-113). Apskritai darbuotojai labiausiai atviravo užduočių paskirstymo klausimu. Suaktyvejjo, nes šis klausimas jiems aktualiausias, taigi turèjo daug ką pasakyti. Tai dar kartą patvirtina, kad darbuotojų požiūris ị organizacijos veiklą yra gana siauras. Kilus abejonių dẻl atliekamų užduočių „labai dažnai“ (V1, 204) pasitariama su darbuotojais. „Jau kartais galvoju per daug jau taip dažnai. Tai aš labai mėgstu. Aš esu apskritai kolektyvo žmogus. Jeigu vadovai mėgsta sèdèti užsidarę duris, pas mane jos visada atidarytos. Ir visada. Ir koks žmogus beateitu, visada rasiu laiko pakalbèti. Ir pasilabinti. Ir jeigu negaliu skirti, visada pasakau: galiu skirti 7 minutes. Galite iš esmès arba, jeigu reikia daugiau laiko, davai sutariame kitą laiką" (V1, 204-208). Darbuotojai pritarè, kad „vadovè taip, teiraujasi, taip, taip“ (FG1, 131), jei kyla abejonių dèl užduoties vykdymo.

Vadove pasakè, ką ji labai vertina: „Aš dievinu žmones, kurie yra atsakingi ir savarankiški. Kai jie patys žino, ką reikia daryti, ir ateina pas mane tartis kaip su lygiaverčiu partneriu. Ne kas 5 minutes laksto: ką čia padaryti, nu, patikrinkit, nu, čia tą. Negaliu aš tokių dalykų. Man tiesiog, nu, nefaina dirbti pačiai. Nes aš tada tampu prievaizdu. Aš nenoriu tokiu tapti. Tai aš formuoju tokią turbūt vadovavimo kultūrą savo skyriuje" (V1, 135-139). İ klausimą, kaip jūs reaguotumète, jeigu viską puikiai atliekantis darbuotojas vis nori pasitikslinti, ar gerai atlieka užduotis, vadovè atsakè: „Žinokite, šnekeečiausi. Aš tikrai šnekeečiausi““(V1, 140-141). Tokiam žmogui sako: „Duodu mėnesị ir arba tu rodai rezultatą, arba mes geruoju išsiskiriame. Aš tiesiog, aš negaliu dirbti tavo darbo ir negaliu sèdeti po darbo. Užtai, kad turiu knistis, nes tu man neduodi atsakymo. Tai mes išsiskyrème“ (V1, 146-148). „Ir prieš priimant tokị sprendimą iš tikrujų kalbẻjausi ir tariausi su keliais komandos nariais, kurie yra man labai svarbūs ir kurių nuomonę aš labai gerbiu ir vertinu. Tai jų nuomonè sutapo su mano nuomone. Ir man beliko priimti sprendimą. Bet tai pats žmogus turëjo galimybę“(V1, 150-152). Matome, kad vadovas skatina darbuotojų atsakingumą ir iniciatyvumą bei siekia rezultatų. Panašu, kad darbuotojai jo prisibijo, nes vis tikslinasi, ar gerai atliko užduotị, bijo suklysti, nes turi darbuotojų atleidimo pavyzdžių.

Išimtị vadovas galètų daryti tik naujam darbuotojui, jei šis nuolat klausinètų, tinkamai ar netinkamai atliko užduotį. Žmogui, kuris gerai atlieka savo darbą, bet vis tiek nuolat klausia nuomonès, ar gerai ji atliko, „turbūt skirčiau savaitei, nežinau, pusvalandị, valandą jo darbams apšnekèti. Jo pagyrai. Nes turbūt, greičiausiai, jam trūksta mano dèmesio. Nu, aš spèju, kad kaip gal, kaip vadovas per mažai pagiriu“ (V1, 158-160); „Aš manau, bandyčiau rasti, ieškoti metodikos kažkokios tai kur. Iš pradžių i savaitę kartą. Paskui retinčiau kas mènesį, jeigu matai, kad viskas OK. Tiesiog taip natūraliai viskas turi nueiti““ (V1, 165-166). Akivaizdu, kad vadovas kalba tariamaja nuosaka, ką darytų, bet praktiškai to nedaro. Taigi yra labai reiklus, dèl to darbuotojai nuolat tikrinasi, ar gerai atliko darbą. Gali būti, kad darbuotojai nepakankamai kvalifikuoti, negeba gerai atlikti darbo, bijo prisiimti atsakomybę, tad apsidrausdami nuolat teiraujasi dèl atlikto darbo kokybès.

Pasiteiravus, ar vadovas aiškina, kodèl vieni ar kiti darbuotojų pasiūlymai yra nepriimtini, gautas atsakymas, kad ,ir taip, ir ne. Yra dalykų, kai tu gali leistis ir aiškinti (V1, 39). Na, jeigu tai yra susiję su mano darbu organizavimu, manau, kad stengiuosi paaiškinti. Šiaip stengiuosi“ (V1, 40-41). Darbuotojų teigimu, „taip, buvo“ (FG1, 41); „Palaiko, jeigu kažką tai nu nori. Ir paaiškina tikrai, man tai paaiškina, kodèl“ (FG1, 44-45). Čia vienas tų retų atvejų, kai darbuotojų ir vadovo nuomonės sutapo. Be abejo, puiku, jei vadovas paaiškina darbuotojų pasiūlymo prièmimo ar atmetimo priežastis.

Vadovas paminèjo ir tai, kad atsiradus papildomų, nenumatytų užduočių, nevengia nepageidaujamų rizikos veiksnių. „Aš nevengiu tokių dalykų. Ir neišvengsi to darbe. Ir negali apsaugoti žmonių nuo tokių dalykų. Nes vienas iš 21 amžiaus rodiklių, apskritai, vienas iš privalumų darbuotojų - mokejjimas veikti vienu metu du, tris darbus. Ir mes, moterys, esame unikalios. Mes tą dalyką sugebame“(V1, 173-176). Matyti, kad vadovas skirsto darbuotojus lytiškumo aspektu. Užduotis, ypač jei jos skubios, skiria atlikti tiems darbuotojams, kurie, žino, kad tikrai galès tai padaryti, nepaisant esamo darbo krūvio. „Žinau pas ką galima nueiti, tą dalyką padaryti. Ir kas tą dalyką padarys. Ir žinau žmogų, kurio negalima tuo metu trukdyti““ (V1, 
177-178). Darbuotojai teigia, kad „stengiasi tikrai““ $(F G 1,117)$ nesukelti nepageidaujamų rizikos veiksnių ir atlikti užduotis, kai vadovas prašo.

I klausimą, ar iniciatyvos nesikerta su etiško vadovavimo nuostatomis, vadovas spontaniškai atsako: „Žiūrint kokios“ (V1, 184). Po pauzès: „Nu, nežinau, žinokit. Dabar galvoju“ (V1, 184). Nurodo atvejį, kai atsisakè paklusti neteisètoms iniciatyvoms iš kito skyriaus. Kadangi tai susiję ir su kitais darbuotojais, dar kels tą klausimą (V1, 189-202). Vadovs teigè, kad „netoleruoju tokių dalykų“ (V1, 202). Darbuotojų teigimu, vadovo iniciatyvos „,ne, nesikerta“ (FG1, 129) su etiško vadovavimo nuostatomis. Malonu girdèti, kad tiek vadovo, tiek darbuotojų požiūris į etiškumą šiuo atveju sutampa.

Vadovas skatina savo darbuotojus būti moraliai atsakingais savo darbinèje veikloje: „O, dar kaip? Dar kaip, iš tikrujų“ (V1, 217). Pasiteiravus, kaip konkrečiai to siekiama, atsakyta: „A, turbūt gerais pavyzdžiais. Stengiuosi pagarsinti. Pati savo pavyzdžiu, iš tikrųjų. Ir ne tiktai savo kolektyve. Bet esame ịkūrę vidinę feisbuko grupę. Tai visi šitie dalykai yra nešami iš mūsų skyriaus, per visą įmonę, nebijant naudoti tuos vadinamus socialinius tinklus. Ir taip toliau“ (V1, 217-220). Darbuotojų nuomone, skatinimo būti moraliais jiems neteko pastebėti: „Ne, ne“ (FG1, 136), nepastebėjo ir informacijos apie teigiamus pavyzdžius.

„Nebuvo dar tokių“ (V1, 223) atvejų šioje organizacijoje, kad reiketų vertinti drausmès pažeidimus moralinių nuostatų aspektu. „Bet jeigu būtų, aiškinčiau priežastis, kodèl“ (V1, 223, 226-227). „Jeigu tai tiesiog žmogaus natūra, tai būtų turbūt vienoks sprendimas arba būtų vienoks pokalbis“(V1, 227-228);. „Apeliuočiau pirmiausiai ị tai, kad jis rodo nepagarbą. Nepagarbą kitiems žmonėms“ (V1, 231-232); „Yra organizacijos nustatytos taisyklès. Ir jų paminti negalima, kad ir kaip norètum, kad ir kokia tavo natūra būtų“ (V1, 232-234); „Kadangi, tai yra organizacija, kurioje aš taip pat dirbu ir aš turiu užtikrinti tam tikrus dalykus, tai toj vietoj ir aš nešu atsakomybę už žmogu““ (V1, 236-237). „Bandyčiau spręsti, kiek tai yra reikalinga“(V1, 238). Tuo tarpu darbuotojai suabejojo, ar vadovas analizuoja netinkamos elgsenos priežastis: „Kažin čia. Iš moralinès, jeigu klaidos kokios, aišku, nagrinejjama, bet, nu, bet ar iš moralinès pusès, čia gal iš profesinès nagrinèjamos, bet ne iš moralinès" (FG1, 142-144). Tyrèjui patikslinus, kad egzistuoja ir profesinè moralè: „Nu, jeigu iš profesinès moralès, tada gali būti“ (FG1, 145-146).

Vadovas teigia, kad stengiasi suburti darbuotojus: „Labai stengiuosi, iš tikrujų. Tą bendruomeniškumo jausmą. Kol kas labai sunkiai, bent jau šitoj organizacijoj sekasi“(V1, 242-243); „Čia pakankamai sudètingai. Nežinau, dar bandau gilintis, kas, kodèl, kur. Bet labai. Man tai bendruomeniškumo jausmas yra žiauriai reikalingas ir naudingas. Ne tik man, bet ir organizacijai ir patys žmonès. Tiesiog“ (V1, 244-246). Tyrëjui pasitikslinus dèl moralinių nuostatų: „„š tikrujų, aš turbūt esu išsikẻlusi labai didelį tikslą šitoj organizacijoj. Tą bendruomeniškumą pirmiausia pas save kolektyve sutvarkyt, tą jausmą tokį. $\mathrm{Nu}$, kad mes esam kaip vienetas. Kad turim eit viens už kitą. Ir savo pavyzdžiu bandyt užkrėst kitus. Nekonkuruojant, o tiesiog ịtraukiant ị projektines veiklas. İtraukiant ị diskusijas. Ir ruošiant kažkokị tai rengini, paklausti pagalbos, kas nori prisidèti. Tiesiog. Tai tikrai, nu, labai sudètingi sąryšiai““ (V1, 249-254). Ir darbuotojai pastebi, kad ,skatinti kaip veiksmas tai yra skatinama. Aš irgi galvoju, kad tai, kad bendrauti, kad, nu, būti“ (FG1, 153-137). Pasiteiravus darbuotojų, ar etiškas požiūris ị kitus darbuotojus, kurie nepriklauso jūsų skyriui, irgi būtinas: „Būtinai tas yra“" (FG1, 155).

Didelè problema šioje organizacijoje ta, ,kad nedeklaruoja savo tikslų, šioje organizacijoje nėra tikslų, tai yra jie yra, bet jie nèra deklaruojami ir apie juos niekas nekalba“ (V1, 256-257). Vadovui būtų sunku išaiškinti, kodèl organizacijos tikslai yra teisingi. Kaip vadovas jis sugebėtų tai padaryti, bet net pats abejoja, ar darbuotojai, kartu ir jis pats tuo patikètų. Tačiau ,aš esu sukūrusi, kaip sukūrusi, aš esu nubrēžusi savo komandos tikslus, apie kuriuos mes kalbam. Ir mes žinom, ką mes norim pasidaryti per šiuos metus. Ką mes norim pasidaryti per kitus metus. Ir kur norim, apskritai, atsidurti po penkerių metų“ (V1, 258-260). Darbuotojai suglumę (matyt, apie ateitị organizacijoje nediskutuojama, ji neplanuojama) ,neaiškiai murma, muistosi“ (FG1, 158); „,Tikslai yra numatyti, ir viskas. O kodèl jie teisingi? Vadovas, vadovas numato ir, ir čia, nu, kaip, čia ne mums spręsti tikriausiai [Tyrẻjas: jums] vertinti, vertinti, nes...“(FG1, 159-160). Pateikus užduotis atsakomybẻ yra ,iš dalies taip, iš dalies nedeleguojama“ (V1, 269); ,Jeigu tai yra visiškai nauja užduoti darbuotojui, turi būti atsakomybė pasidalinta tarp manęs ir tarp to žmogaus" (V1, 270-272). Darbuotojui duodama suprasti, kad prireikus jis gali kreiptis ị vadovą ir jam bus padèta. Tačiau, jei jis nesikreipia ir pats viską daro, tai atsakomybė yra tik jo, asmeniška. Darbuotojai teigia, kad priimant galutinị sprendimą dèl užduočių „tiesiog apsitariama, nežinau, kad 
būtų laikytasi įstatymų. Gal nesėdim ir nediskutuojam, ar čia sąžininga, ar čia nepakenks kažkam, nežinau per tą tokị vidinị (supratimą), bet tai, kad viskas būtų tvarkingai, įstatymiškai padaroma“ (FG1, 183-185); „Aš labai tikiuosi, iš tikrujų darbuotojai imasi iniciatyvų ịgyvendinimo“ (V1, 284); „Aš už iniciatyvas“ (V1, 288). Darbuotojai teigè, kad dirbdami su vadovu, kuris buvo prieš dabartinį, „buvom ịpratę, nu, kaip, daugiau savarankiškai dirbti“" (FG1, 199). O dabar visos iniciatyvos - tik su vadovo žinia ir yra „daug daugiau kontrolès“ (FG1, 200). Akivaizdus neatitikimas tarp vadovo ir darbuotojų žodžių. Nors vadovas teigia ir vis kartoja, kad siekia darbuotojų iniciatyvumo, darbuotojai teigia priešingai, kad lyg ir skatina, bet visi klausinejja vadovo apie darbų kokybę, nes bijo prisiimti atsakomybę. Taigi mano, kad anksčiau darbe buvo daugiau savarankiškumo.

„Aš labai prašau $(V 1,290)$ pasidalinti žiniomis atliekamos užduoties atžvilgiu. Man pačiai labai įdomus tas grị̌ztamasis ryšys. Aš kartais galvoju: Jėzus, aš kaip mama“ (V1, 290-291). Darbuotojai patvirtino [linksẻdami galvomis], „taip“ (FG1, 203), vadovas prašo pasidalinti savo žiniomis dèl atliekamų užduočių. Vadovas teigia, kad ,žodžiais, veiksmais, patarimo klausdama, netgi kai leidžiu pačiam žmogui prieš skiriant užduotį tiesiog pasakyti ir paklausti, o kaip tu darytum, ką tu manai“ (V1, 293-294), tai rodo pasitikejjimą savo darbuotojais. Darbuotojai mano, kad pasitikèjimas jais „rodomas vien pagal darbų skyrimąa“ (FG1, 205) ir grịžtamajị ryšị supranta tik kaip papildomą kontrolę.

Vadovas mano, kad savo tinkamo elgesio pavyzdžiu skatina darbuotojus laikytis etinių normų. „Aš noriu taip, kad man būtų gera ir kolegom gera“ (V1, 310). Darbuotojai atsako, kad nepastebejo ir nemano, jog vadovas gali būti pavyzdys: „Ne, nežinau, ne“ (FG1, 210). Organizacijoje darbuotojai neskatinami laikytis etinių normų. Vadovas teigia, kad neskatina darbuotojų laikytis etikos normų. Tačiau, ,jei matyčiau, kad kažkas elgiasi neetiškai arba man atrodo, kad jau perženge žmogiškumo vertybes, aš turbūt ịsikiščiau ir neleisčiau“ (V1, 312-314); „Bent jau pastabą tikrai pasakyčiau“ (V1, 314). Tačiau darbuotojai mano, kad „nu dar man neteko (FG1, 225) tai pamatyti“. Iš esmès darbuotojų atsakymai atskleidè, kad vadovu jie nepasitiki, nèra pastebejję, kad stabdytų neetišką elgseną. „Aš stengiuos (V1, 319) skatinti atsakingą elgseną įgyvendinant užduotis atsižvelgiant ị etines normas. Manau, kad tas dalykas (atsakinga elgsena) yra ir turi nemažą užuomazgą šitoj organizacijoj“ (V1, 322-323). Darbuotojams iš viso sunku kalbèti apie organizacijoje puoselèjamas vertybes. Vadovas tikisi, „kad yra“ (V1,330) kuriamas abipusis pasitikejjimas, laikantis etinių normų. Dažniausia darbuotojai klausimais apie vertybes neturi jokios nuomonès. Kalbant apie vertybes, moralę, kyla jausmas, kad jie nejaukiai jaučiasi (savotiškai gūžiasi). Manytume, kad su jais apie tai nekalbama.

Vadovo teigimu, jis skatina darbuotojus atvirai, atsakingai ịvardyti esamas negeroves: „Aš labai skatinu kalbèti žmones. Aš netgi per daug. Ta prasme, aš labai skatinu rinktis, labai skatinu kalbėtis“(V1, 396-397). Šiuo klausimu darbuotojų nuomonès išsiskyrè: vieni teigè, kad „nesakom, geriau jau nesakyti (apie negeroves)“ (FG1, 271), kiti abejojo, ,gal ir pasakysiu“ (FG1, 272), dar kiti teigè, kad „kaip tik norisi kažką pakeisti, palengvinti“ (FG1, 272273) pasisakant apie negeroves. Taigi akivaizdu, kad atvirumo organizacijoje trūksta, darbuotojai yra tik vykdytojai ir net matydami organizacijoje esant problemų apie jas nekalba, nes tai „ne jų reikalas“.

Matome, kad nepaisant panašių ar skirtingų vadovo ir darbuotojų atsakymų, egzistuoja ne tik nuomonių skirtumai, bet ir tam tikra priešiška darbuotojų reakcija į vadovo elgseną. Nors vadovas stengiasi (arba tik taip ịtikinamai kalba tyrejjams) keisti nusistovejusią ịprastą tvarką, darbuotojams vis dar labiau priimtina, kad vadovas nereikalautų iniciatyvumo ir atsakomybès, tiesiog leistų jiems atlikti priskirtą darbą, kaip buvo vadovaujant ankstesniam vadovui. Gana keista, bet 6 fokus grupès nariai ị pateiktus klausimus atsakè beveik vienodai, nuomonès neišsiskyrè net minimaliai. Ši tyrimą puikiai papildytų stebèjimo metodu atliktas tyrimas, tada būtų matyti, kaip iš tiesų elgiasi vadovas ir darbuotojai.

\section{Išvados}

Etiškas vadovavimas organizacijoms, be abejo, yra svarbus. Dažnu atveju tai pripažįsta visų organizacijų vadovai, darbuotojai, mokslininkai ir tyrèjai. Kyla elementarus klausimas, kodèl ne visos organizacijos etiško vadovavimo principu laikosi, juk etiškai vadovaujant įtraukiami darbuotojai, jie raginami mokytis, skatinama nuomonių ịvairovè, sudaromos tinkamos darbo sąlygos, darbe tobulinami ir kuriami etiški tarpusavio santykiai, puoselèjamas bendruomeniškumas, raginama prisiimti atsakomybę, darbuotojams nustatomi prioritetai etiškumo aspektu, kuriama pasitikejimo kultūra. 
Analizuojant tyrimo rezultatus susidaro dvejopas įspūdis. Viena vertus, vadovas tikisi darbuotojų atsakingumo, savarankiškumo, etiško elgesio, kita vertus, remdamiesi darbuotojų atsakymais, galime suprasti, kad jie vadovo šiek tiek prisibijo, tad nenori rodyti iniciatyvos, net ir matydami tam tikras problemas organizacijoje, jų neįvardytų. Panašu, kad darbuotojams nepatinka vadovo vadovavimo stilius, požiūris, jie noretų tikslių užduočių formuluočių, kita vertus, tarsi ir nori, kad juos išklausytų, paisytų jų nuomonès, bet atsakomybės prisiimti neketina. İdomu būtų išgirsti aukštesnio lygmens vadovų požiūrị i š šiame padalinyje esamą nesusikalbẻjimą, ar šis vadovas priimtas, siekiant pakeisti organizacijoje senokai nusistovejjusią kultūrą, išjudinti darbuotojus, ar tam, kad siektų rezultatų, bet laikytųsi metų metus vyravusios tvarkos ir pats prie jos prisitaikytų.

Apibendrinant tyrimo rezultatus etiško vadovavimo tema galima teigti, kad organizacijoje tam dèmesio skiriama nedaug, nors neetiškos elgsenos apraiškų taip pat beveik nepastebèta.

\section{Literatūra}

Aghiorghiesei, D. T., Poroch, V., Perțea, M. (2015). Ethical Leadership in Healthcare Institutions from Romania. An Approach from a Management Perspective. Revista Română de Bioetică. Romania, Iaşi: Colegiul Medicilor Iaş̧i, Vol. 13, Nr. 1, p. 186-207. ISSN 1583-5170.

Alshammari, A., Almutairi, N. N., Thuwaini, Sh. F. (2015). Ethical Leadership: The Effect on Employees. International Journal of Business and Management, Vol. 10, No. 3, p. 108-116. Toronto: Canadian Center of Science and Education. ISSN 1833-3850.

Bass, B. M., Steidlmeier, P. (1999). Ethics, character, and authentic transformational leadership behavior. Leadership Quarterly, Vol. 10, No. 2, p. 181-217. ISSN 1048-9843.

Chin, T. (2013), How ethical leadership encourages employee voice behavior in China: The mediating role of organizational harmony. International Business Research, Vol. 6, No. 10, p. 15-24.

Choi, So-Yun (2015). The Effects of Ethical Management on Social Worker's Organizational Commitment and Turnover Intention. Advanced and Technology Letters, Vol. 91, p. 32-38. Australia, Tasmania: SERSC. ISSN 2287-1233.

Ciulla, J. B. (2004), Ethics and Leadership Effectiveness. In: J. Antonakis, A. Cianciolo, R. Sternberg. The Nature of Leadership. London, New Delhi: Sage Publications, Thousand Oaks, p. 302-327.

Derr, C. L. (2012), Ethics and Leadership. Journal of Leadership, Accountability and Ethics, Vol. 9(6), p. 66-71.

Yates, L. A. (2014), Exploring the Relationship of Ethical Leadership with Job Satisfaction, Organizational Commitment, and Organizational Citizenship Behavior. The Journal of Values-Based Leadership, Vol. 7, Issue 1, p. 22-36. ISSN 1948-0733.

Kardelis, K. (1997). Moksliniu tyrimu metodologija ir metodai. Kaunas: Technologija. ISBN 9986-13-561-3.

Khodarahmi, R., Aghahoseini, T. (2014). The Relationship between Ethical Leadership and Empowerment of Employees in the Tax Affairs of Isfahan City. International Journal of Academic Research in Business and Social Sciences, Vol. 4, No. 6, p. 279-293.

Kothari, C. R. (2004). Research methodology. Methods and techniques. New Delhi: New age international (p) limited, publishers. ISBN (13):978-81-224-2488-1.

Mayer, D. M., Kuenzi, M., Greenbaum, R. L. (2010). Examining the Link between Ethical Leadership and Employee Misconduct: The Mediating Role of Ethical Climate. Journal of Business Ethics, Vol. 95, p. 7-16.

Mihelič, K. K., Lipičnik, B., Tekavčič, M. (2010), Ethical Leadership. International Journal of Management \& Information Systems, Vol. 14, No. 5, p. 31-42.

Nyukorong, R. (2014), Fostering ethical leadership in organizations. European Journal of Business and Management, Vol. 6, No. 33, p. 56-63.

Obicci, P. A. (2015). Effects of ethical leadership on employee performance in Uganda. Net Journal of Business Management, Vol. 3(1), p. 1-12.

Pandey, P., Singh, S., Pathak, P. (2015), Ethical leadership: the need for a new approach in retail. Purushartha Journal, Vol. 8, No. 1, p. 91-99.

Rowe, W. G., Guerrero, L. (2013). Cases in Leadership. USA. Sage Publicationes, Ins. ISBN 978-1-4522-3497-7.

Rupšiené, L. (2007). Kokybiniu tyrimu duomenu rinkimo metodologija. Klaipėda: KU. ISBN 978-955-18-248-1.

Stelmokienè, A., Endriulaitienè, A. (2013). Vadovo efektyvumo vertinimo pagrindimas: ar reikalinga teorinių požiūrių gausa? Organizaciju vadyba: sisteminiai tyrimai, Nr. 68, p. 109-122. ISSN 1392-1142.

Tidikis, R. (2003). Socialiniu mokslu tyrimu metodologija. Lietuvos teisès universiteto leidybos centras. Kaunas: Aušra. ISBN 9955-563-26-5.

Treviño, L. K., Brown, M. E. (2004a). The Role of Leaders in Influencing Unethical Behavior in the Workplace. In: R. E. Kidwell Jr., C. L. Martin. Managing Organizational Deviance. London, New Delhi: Sage Publications, Thousand Oaks, p. 69-96. 
Treviño, L. K., Brown, M. E. (2004b). Managing to be ethical: Debunking five business ethics myths. Academy of Management Executive, Vol. 18, No. 2, p. 69-81.

Zhu, W. (2008). The Effect of Leadership on Follower Moral Identity: The Mediating Role of Psychological Empowerment, Leadership Review, Vol. 8, p. 62-73. Kravis Leadership Institute. ISSN 1539-6363.

\title{
THE MANIFESTATION OF ETHICAL LEADERSHIP IN AN ORGANISATION
}

\author{
Arnoldas Petrulis, Ligita Šimanskienė, Darius Burgis, Jurgita Paužuolienė \\ Klaipėda University (Lithuania)
}

Summary

The article shows the importance of ethical leadership in organisations. Ethical leadership is the behaviour of a leader based on a positive personal example, personal values, and universally acceptable ethical norms, aimed at directing the activities of employees, the organisation and society to achieve their goals through trust. In the article, we formulate two questions: Is ethical leadership inherent in an organisation? What is the approach of the manager and his immediate subordinates to ethical leadership? The goal of the study is to reveal the manifestation of ethical leadership in an organisation.

Research methods: the analysis of scientific literature, synthesis, and comparison. Two qualitative studies were used: focus group interviews for employees, and the interview method for managers. After the interviews, the data was transcribed, and a graphic representation of data was used.

The results of the study show that, in part, ethical leadership is manifested in the organisation, and the manager is guided by ethical principles. The attitude to ethical leadership of the manager and his direct subordinates frequently differs. The analysis results in a two-fold impression. On one hand, the manager wants staff to be accountable and autonomous, and to act ethically. But we understand from the employees that they are slightly afraid of the manager, and are reluctant to show initiative. Even if they saw problems in the organisation, they would not point them out to the manager. The employees seem to dislike the leadership style and attitude of the manager. They would like a more precise formulation of their tasks. Although they would like their opinions to be heard, they do not want to bear responsibility. It would be interesting to hear the views of managers on this situation: to understand whether a manager was appointed to replace the established culture in the organisation, to stir up employees; or whether the manager was appointed to achieve results, but to follow and adapt to the established order. To sum up the results of the study, we can say that not a lot of attention is paid to ethical leadership in the organisation, but not many manifestations of unethical behaviour were detected.

KEY WORDS: ethical leadership, manager, focus group, interview.

JEL CLASSIFICATION: M12, O15

Gauta: 2020-01-02

Priimta: 2020-02-01

Pasirašyta spaudai: 2020-02-10 